\title{
Metacognitive skill on students of science education study program: Evaluation from answering biological questions
}

\author{
Mochammad Yasir a,1,* ${ }^{\text {, }}$ Aida Fikriyah ${ }^{a, 2}$, Nur Qomaria ${ }^{a, 3}$, Aushia Tanzih Al Haq b,4 \\ a Department of Science Education, University of Trunojoyo Madura, Telang Street PO Box 2 Kamal, Bangkalan City 69162, Indonesia \\ ${ }^{b}$ Department of Life Science, National Central University, Number 300, Zhongda Road, Zhongli District, Taoyuan City 32001, Taiwan \\ ${ }^{1}$ yasir@trunojoyo.ac.id *; 2 aida.fikriyah@trunojoyo.ac.id ; ${ }^{3}$ nur.qomaria@trunojoyo.ac.id ; ${ }^{4}$ aushia.tanzia@nhri.edu.tw \\ * Corresponding author
}

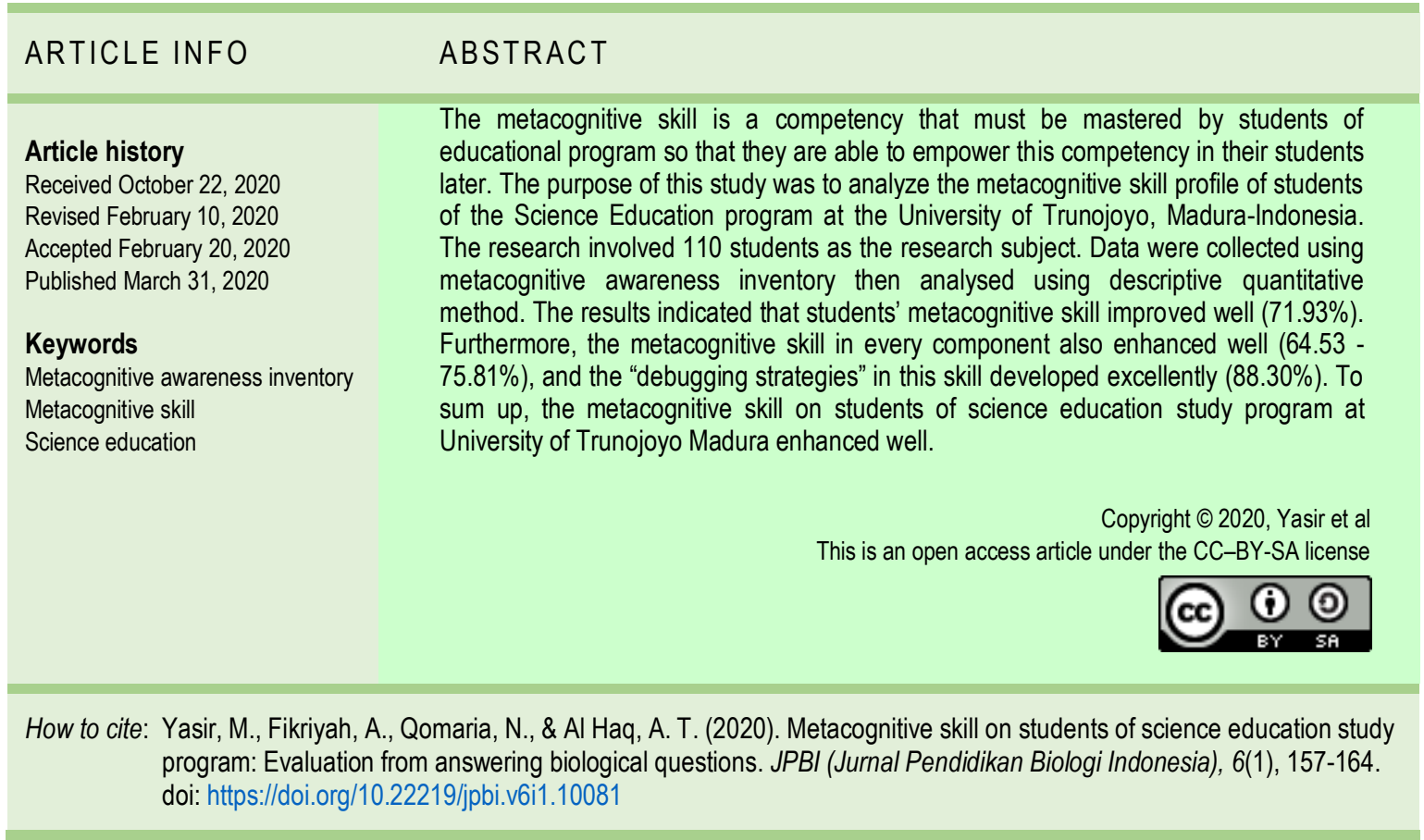

\section{INTRODUCTION}

In the current era, the teachers are not only required to deliver learning materials but also empower various 21st-Century competencies (Docherty, 2018; Serdyukov, 2017; Wilson \& Bai, 2010). Various thinking skills that are the foundation of $21 \mathrm{st}$-Century skills must be known and understood by the teachers and the way they are empowered must be known (AACTE, 2010; Darling-Hammond, Flook, Cook-Harvey, Barron, \& Osher, 2019). According to several thinking skills, metacognitive skills become essential skills that also support and relate to other skills (Blummer \& Kenton, 2014; Chauhan \& Singh, 2014; Demirel, Aşkın, \& Yağcı, 2015).

The empowerment of metacognitive skills is seen as an urgent for several reasons. First, metacognition is closely related to a student's ability to deal with problems while learning (Chauhan \& Singh, 2014). Second, metacognition can also support students in the problem solving process (Persky, Medina, \& Castleberry, 2018). Third, metacognition is also related to cognitive and self-regulatory control abilities in students (Efklides, 2014). Moreover, this competency can maximize personal development, academic writing skills, and mastery of concepts (Sudarmin et al., 2016). 
Through the empowerment of metacognitive skills during learning, the learning process becomes more effective because students can evaluate their own understanding (Chauhan \& Singh, 2014). They will also be able to increase their learning motivation (Yanqun, 2019). Furthermore, through the empowerment of metacognitive skills, students' thinking skills also will be increased. Some of the thinking skills reported have also increased when metacognitive skills have increased, including critical (Lukitasari, Hasan, \& Murtafiah, 2019; Magno, 2010; Naimnule \& Corebima, 2018) and creative thinking skills (Hargrove \& Nieffeld, 2015; Jia, Li, \& Cao, 2019; Suratno, Komaria, Yushardi, Dafik, \& Wicaksono, 2019).

The teacher as the main component in the learning process is also expected to have good metacognitive skills. The better the teacher's metacognitive skills, the more optimal the empowerment of these competencies. Therefore, prospective teachers must have good metacognitive skills (Ahmad Fauzi \& Sa'diyah, 2019). The reason is, it is not possible for a person to be able to empower metacognitive skills well if he himself does not master these skills (Bahri, Idris, Nurman, \& Ristiana, 2019; Jiang, Ma, \& Gao, 2016; Suratno et al., 2019).

Beside teacher factor, learning materials also play a role in empowering metacognitive skills. Some materials have a higher potential for empowering skills than others (Broom, 2015; Gullan, Power, \& Leff, 2013; Sewagegn \& Diale, 2019). One material that has a potential to empower metacognitive skills is biology (Djamahar et al., 2019; Hartman, 2001; Rahmat \& Chanunan, 2018; Setiawati \& Corebima, 2018; Siegesmund, 2016; Zohar \& Barzilai, 2013; Zulfiani, Rosyidatun, Hasiani, Rohmatullah, \& Zuqistya, 2018). Through presenting various biological problems, students can be trained to improve their metacognitive skills. Some indicators that can be used to evaluate their metacognitive skills when solving biological problems, include the accuracy of the argument, systematic in responding to problems, and skills in using language when solving problems (Corebima, 2009).

Ethnoscience is one of lectures that have to be learned by students in Science Education study program. Regarding to this lecture, it discusses about the learning process which links on the relationship between scientific knowledge, local culture, and indigenous science (Sudarmin et al., 2016). Ethnoscience is important to be mastered since it supports the Curriculum 2013 and its relationship between $21^{\text {st }}$-Century skills (Sudarmin, 2014). The Curriculum 2013 can support students to link the science knowledge and culture (Kemendikbud, 2014). As we know, Indonesia has a diverse culture, but has not been widely used as a material of science learning. As the impact, Indonesia culture and local wisdom are continually left and forgotten by society, especially students. Therefore, pre-service science teachers need to empower this subject in order can transfer this to their students later.

During ethnoscience learning process, one of higher thinking skill that have to be taught to pre-service teacher is metacognitive skill. This skill is important to be empowered since it will be used in analyzing and identifying various problems related to biology phenomenon and absolutely also in solving those authentic problems (Chauhan \& Singh, 2014; Persky, Medina, \& Castleberry, 2018). According to the observation result, it also can be concluded that students' metacognitive skill still needs to be improved during the learning process, especially on the aspect of planning, monitoring, and evaluating.Responding to the importance of metacognitive skills, various studies examining metacognitive skills in Indonesia have been conducted several times. From the various reports, it was found that some forms of learning can improve this competency (Siregar, Susilo, \& Suwono, 2017; Tamsyani, 2016). The development of modules and learning media was also carried out by previous researchers to streamline the empowerment of metacognitive skills (Dewi, Kannapiran, \& Wibowo, 2018; Siagian, Saragih, \& Sinaga, 2019). However, from the many studies that have been conducted, the assessment of the metacognitive skills profile of prospective teacher students is still difficult to find. Its difficulty is caused by the type of instrument in which generally the instrument used to evaluate metacognitive skill is only in the form of questionnaire. Moreover, the metacognitive skill which is a part of cognitive domain can be analysed and evaluated using a test instrument. This kind of research is important because it can be important information in evaluating the quality of teacher education through such kind of test instrument modified from Schraw and Dennison (1994). Therefore, the purpose of this study was to analyze the metacognitive skills of students majoring in science education to respond to biological questions.

\section{METHOD}

This study was a case study research, involving 110 students of Science Education Study Program at University of Trunojoyo Madura. The research subject involved students from class A, B, and C in the academic year of 2018. Students were taught Ethnoscience lecture during one semester, and the metacognitive skill on students were evaluated. Data were collected through Metacognitive Awareness Inventory (MAl) with adapting from Schraw and Dennison (1994). This test instrument consisted of 15 essay question items asking the concepts of Genetics on Human and its relationship with Ethnic and Society on Madura, East Java-Indonesia. 
The metacognitive test was arranged in several indicators and sub-indicators. The first indicator was declarative knowledge with three sub-indicators; identifying the problem, analysing the prior knowledge to solve the problem, and examining own weakness and capabilities, on item number 1,2, and 15. Furthermore, the second indicator asked about procedural knowledge with two sub-indicators; giving the alternative solutions to overcome problem and providing steps or ways to solve problem, on item number 6 and 7 . The third indicator was about indicator of conditional knowledge in which the sub-indicators were about deciding the best answer and giving reasons of choosing that answer, on item number 8 and 10. Furthermore, the forth indicator was about planning with two sub-indicators; relating the prior knowledge and new information to solve the problem, and arranging plan to solve problems on item number 3,4 , and 5 . The fifth indicator was about monitoring with two-sub indicators; evaluating the formula that was used to solve the problem related to human genetics and analysing strategies that are used to correct the results, on item number $9,11,12$, and 13 . Finally, the last indicator was about evaluation with one sub-indicator; re-checking the assignments, on item number 13 and 14.

The obtained result of study were analyzed using quantitative descriptive method. Data of metacognitive skill obtaining from test score was converted using the Formula 1 based on Corebima (2009) where $y 1$ is cognitive test score, $y 2$ is the combination of cognitive and metacognitive test score, and $x$ is metacognitive skills score. Findings were also obtained from the metacognitive questionnaire in which it used Guttmann scale (Abdi, 2010), with score 1 and 0 , then the total score was categorized based on the interval on Table 1. Finally, the level of metacognitive skill was determined using criteria on the Table 2.

$y_{2}=\frac{y_{1}+2 x}{2}$

Table 1. Interval of metacognitive skill

\begin{tabular}{clccc}
\hline Component on metacognitive & Indicator & Good & Moderate & Bad \\
\hline Cognitive & Declarative & $6-8$ & $3-5$ & $0-2$ \\
& Procedural & $5-6$ & $2-4$ & $0-1$ \\
& Conditional & $4-5$ & $2-3$ & $0-1$ \\
Psychomotor & Planning & $6-7$ & $2-5$ & $0-1$ \\
& Monitoring & $6-7$ & $2-5$ & $0-1$ \\
& Evaluating & $4-5$ & $2-3$ & $0-1$ \\
\hline
\end{tabular}

Source: Adapted from Corebima (2009) and Yasir (2015)

Table 2. Criteria of metacognitive skill level

\begin{tabular}{cl}
\hline Level of metacognitive & \\
\hline Excellent & 1. Declarative, procedural, and conditional skills developed well. \\
& 2. Planning, monitoring, and evaluating skills enhanced well. \\
Good & 1. Declarative and procedural skills developed well but conditional skill reached on moderate level. \\
& 2. Planning and monitoring skills developed well but evaluating skills reached on moderate level. \\
Moderate & 1. Declarative developed on moderate level but conditional and procedural skills reached on bad level. \\
& 2. Planning developed on moderate level but monitoring and evaluating skills reached on bad level. \\
Bad & 1. Declarative, procedural, and conditional skills developed poorly. \\
& 2.Planning, monitoring, and evaluating skills enhanced poorly. \\
\hline
\end{tabular}

Source: Adapted from Corebima (2009) and Yasir (2015)

\section{RESULTS AND DISCUSSION}

Metacognition is an important competency that needs to be optimally empowered at all levels of education. The metacognitive skills of the students on science education study program involved in this study are presented in Table 3 and the level of each component of their metacognition is presented in Figure 1. Based on Table 3, the metacognitive skills on students in class A, B, and C have developed well, showed by the average of $72.93 \%$. Furthermore, it also can be seen that the each metacognitive skill component reached on score above 60 (Figure 1). Data in the Figure 1 indicates that students' metacognitive skill in all components has developed well, showed in percentage of declarative knowledge skill $(75.81 \%)$, procedural knowledge $(71.46 \%)$, conditional knowledge $(73.80 \%)$, planning $(64.53 \%)$, information management strategy $(67.60 \%)$, comprehension monitoring $(65.78 \%)$, and evaluation $(68.50 \%)$. Meanwhile the skill of debugging strategies reached the highest percentage which means that this skill has developed very well $(88.30 \%)$. 
Table 3. Data of students' metacognitive skill in every class

\begin{tabular}{ccc}
\hline Class & Metacognitive skill $(\%)$ & Category \\
\hline A & 72.03 & Developed well \\
B & 75.38 & Developed well \\
C & 70.38 & Developed well \\
\hline
\end{tabular}

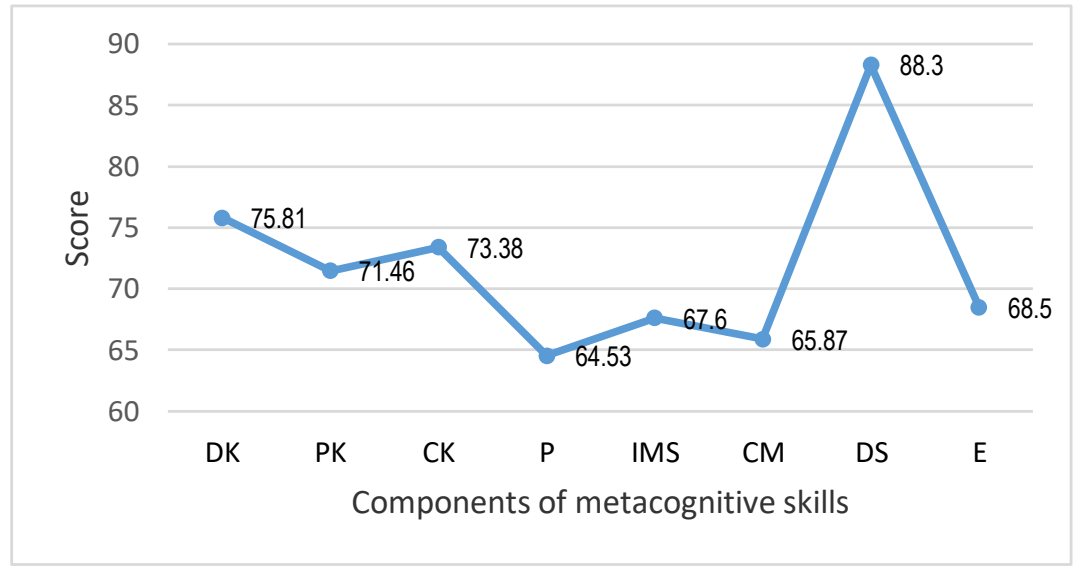

Figure 1. Students' metacognitive skill in every component (DK: Declarative Knowledge, PK: Procedural Knowledge, CK: Conditional Knowledge, P: Planning, IMS: Information Management Strategies, CM: Comprehension Monitoring, DS: Debugging Strategies, E: Evaluation)

The good profile of metacognitive skills of students analyzed in this study is not in line with some previous studies. Some previous studies conducted in Indonesia have reported that the metacognition profile of students is still unsatisfactory. These studies are not only conducted at middle school (Diella \& Ardiansyah, 2017; Nurajizah \& Windyariani, 2018; Tjalla \& Putriyani, 2018), but also higher education (Ahmad Fauzi \& Sa'diyah, 2019). Therefore, findings in this study showed that learning process especially in Science Education study program is conducted well by enhancing metacognitive skill. It is supported that metacognitive skill can enhance well if it is implemented continually during the learning process.

The difference results between researches that was conducted in middle school with this present research can be happened due to the difference of education level of research subject. The statement is based on the information from previous research that inform level of education has an essential factor in contributing student thinking skills (Coşkun, 2018). Education level has an impact on metacognitive skills due to these competencies can improve when students regularly use their cognitive. Therefore, the longer the students involved in education processes, the higher their metacognitive skills (Ahmad Fauzi \& Sa'diyah, 2019).

Then, the difference results between the finding between this present research and the previous research that conducted in the other higher education program and institution can be happened due to the difference learning activities experienced by research subjects. The good profile of metacognitive skills of students in science education program that involved in this research indicated that the course activities that held in this study program could empowered metacognitive skills. Learning activities have been known as main factor affect students metacognitive level (Aydin, 2011; Zohar \& Barzilai, 2013).

However, results of this study indicate that students' declarative skill has increased well, but less optimal. It is also assumed that students were not able to control their meta-comprehension skill since they were difficult in monitoring their selves. If this ability is low, then students will face difficulties in understanding concepts well (Sudarmin et al., 2016). This condition reveals that several students still found difficulties on facing and analysing problems related to Ethnoscience, especially in the concepts of Genetics on Human and its relationship between Ethnic and Social.

Furthermore, based on Figure 1, the students' procedural knowledge skill has increased well. However some of them still need assistance in applying cognitive strategy during the learning process. Procedural knowledge skill is related to the way of doing something. Several strategies can be implemented to rise metacognitive skill such as by getting students to identify what they already know and do not know, re-tell about their thinking, arrange plans, identify questions, and evaluate their selves (Corebima, 2016; Sudarmin et al., 2016). 
Then, conditional knowledge is a skill to decide when declarative and procedural knowledge will be applied during the learning process. It is found in this study that students' conditional knowledge has developed well. However, some of them still were not capable to understand in learning strategy decision. Students should be used to decide what learning strategy that will be used to learn since it can enhance thinking skill. Use of various learning strategies will make learning process easier.

Planning ability is also one of skill in metacognitive which is related to arrange plan of learning activity. Findings in this study showed that students were not capable to control their selves before start the learning process, most of them also did not state learning aims, and manage time of learning. However, it can be assumed that this skill is really important to be applied during the learning process since it can affect on the learning achievement.

Furthermore, information management strategy related to the skill to analyze and identify ideas and use learning strategy to make meaningful information. It is found in this study that students were used to read text book in learning. Furthermore, the other component in metacognitive skill is comprehension monitoring which includes the evaluation of learning activity and strategy. Students should be used to evaluate themselves since it is advantageous to understand which the best learning strategy that is suitable with their needs and personality.

The last component is debugging strategies in which students in this study reached the highest score. It is assumed that students were able to revise wrong understanding and assignments. However, it should be always implemented during the learning process to make the metacognitive skill in all components can develop very well.

To sum up, according to the findings obtained in this study, students' metacognitive skill reached on $71.93 \%$ meaning that it has developed well. However, it is found that the weakness related to the students' metacognitive skill in this study should be solved effectively by applying several learning strategies, for instance by applying mind mapping or concept mapping. Metacognitive skill is not an inherited skill however it can be taught continually through active learning. Through various activities such as keeping a reflective journal, talking about thinking, and self-questioning, it is expected that students are able to enhance their metacognitive skill and thus can be implemented when they work and interact with society. Some references suggest a active learning such as mind-mapping (Pedone, 2014). self-reflection activities (Colbert et al., 2015), as well as inquiry learning (Adnan \& Bahri, 2018). Moreover, several learning model have also been confirmed could improve students' metacognitive skills. Some of the learning model is project-based learning (Sumampouw, Rengkuan, Siswati, \& Corebima, 2016) and problem-based learning (Haryani, Masfufah, Wijayati, \& Kurniawan, 2018; Panchu, Bahuleyan, Seethalakshmi, \& Thomas, 2016).

\section{CONCLUSION}

According to the findings of this study, it can be concluded that: the students' metacognitive skill has developed well with the average of $71.93 \%$. Furthermore, the students' metacognitive skills in every component also developed well $(64.53-75.81 \%)$, except the ability of debugging strategies which enhanced excellently $(88.30 \%)$. This study has examined the profile of metacognitive skills of students of science education courses. The results of the analysis have shown that their metacognitive skills are good. However, this conclusion is only based on metacognition data that collected using one instrument. Therefore, further research involving more than one type of metacognition instrument needs to be done. In addition, to confirm the effectiveness of lectures in science education in empowering metacognition, research that examines the metacognition profile in various study programs needs to be conducted.

\section{ACKNOWLEDGMENT}

We would like to thank to Directorate of Research and Community Service of University of Trunojoyo Madura-East Java, Indonesia who has supported fully on this study. We are also immensely grateful to all colleagues from Department of Science Education- University of Trunojoyo Madura for their comments and suggestions on this manuscript, although any mistakes are ours and may not tarnish the reputations of these persons. 


\section{REFERENCES}

AACTE. (2010). 21st century knowledge and skills in educator preparation. Retrieved from Pearson website: https://files.eric.ed.gov/fulltext/ED519336.pdf

Abdi, H. (2010). Guttman scaling. In N. Salkind (Ed.), Encyclopedia of research design (pp. 1-5). Retrieved from https://personal.utdallas.edu/ herve/abdi-GuttmanScaling2010-pretty.pdf

Adnan, A., \& Bahri, A. (2018). Beyond effective teaching: Enhancing students' metacognitive skill through guided inquiry. Journal of Physics: Conference Series, 954, 012022. doi: https://doi.org/10.1088/17426596/954/1/012022

Aydin, F. (2011). Geography teaching and metacognition. Educational Research, 6(March), 274-278. Retrieved from https://eric.ed.gov/?id=EJ923659

Bahri, A., Suryani Idris, I., Nurman, R., \& Ristiana, E. (2019). PBLRQA strategy potential in enhancing metacognitive skills of students with different academic achievement. Journal of Physics: Conference Series, 1317(1). doi: https://doi.org/10.1088/1742-6596/1317/1/012199

Blummer, B., \& Kenton, J. (2014). Promoting metacognition. In B. Blummer \& J. Kenton (Eds.), Improving student information search: A metacognitive approach (pp. 89-100). doi: https://doi.org/10.1533/97817 80634623.89

Broom, C. (2015). Empowering students: Pedagogy that benefits educators and learners. Citizenship, Social and Economics Education, 14(2), 79-86. doi: https://doi.org/10.1177/2047173415597142

Chauhan, A., \& Singh, N. (2014). Metacognition: A conceptual framework. International Journal of Education and Psychological Research, 3(3), 21-22. Retrieved from http://ijepr.org/doc/V3_Is3_Oct14/ij4.pdf

Colbert, C. Y., Graham, L., West, C., White, B. A., Arroliga, A. C., Myers, J. D., ... Clark, J. (2015). Teaching metacognitive skills: Helping your physician trainees in the quest to 'know what they don't know.' The American Journal of Medicine, 128(3), 318-324. doi: https://doi.org/10.1016/j.amjmed.2014.11.001

Corebima, A. D. (2009). Metacognitive skill measurement integrated in achievement test. Third International Conference on Science and Mathematics Education. Retrieved from https://scholar.google.com/scho lar?cluster $=12596119987386130601 \&$ hl=en\&oi=scholarr

Coşkun, Y. (2018). A study on metacognitive thinking skills of university students. Journal of Education and Training Studies, 6(3), 38-46. doi: https://doi.org/10.11114/jets.v6i3.2931

Darling-Hammond, L., Flook, L., Cook-Harvey, C., Barron, B., \& Osher, D. (2019). Implications for educational practice of the science of learning and development. Applied Developmental Science, O(0), 1-44. doi: https://doi.org/10.1080/10888691.2018.1537791

Demirel, M., Aşkın, İ., \& Yağcı, E. (2015). An investigation of teacher candidates' metacognitive skills. Procedia - Social and Behavioral Sciences, 174, 1521-1528. doi: https://doi.org/10.1016/j.sbspro.2015. 01.783

Dewi, N. R., Kannapiran, S., \& Wibowo, S. W. A. (2018). Development of digital storytelling-based science teaching materials to improve students' metacognitive ability. Jurnal Pendidikan IPA Indonesia, 7(1), 16-24. doi: https://doi.org/10.15294/jpii.v7i1.12718

Diella, D., \& Ardiansyah, R. (2017). The correlation of metacognition with critical thinking skills of grade XI students on human excretion system concept. Jumal Penelitian dan Pembelajaran IPA, 3(2), 134-142. doi: https://doi.org/10.30870/jppi.v3i2.2576

Djamahar, R., Ristanto, R. H., Sartono, N., Ichsan, I. Z., Darmawan, E., \& Muhlisin, A. (2019). Empowering student's metacognitive skill through Cirsa learning. Journal of Physics: Conference Series, 1227(1), 18. doi: https://doi.org/10.1088/1742-6596/1227/1/012001

Docherty, M. (2018). Teaching the next generation: Engaging and empowering the learners of tomorrow. INTED2018 Proceedings, 1(March), 1030-1039. doi: https://doi.org/10.21125/inted.2018.0121

Efklides, A. (2014). How does metacognition contribute to the regulation of learning? An integrative approach. Psihologijske Teme, 23(1), 1-30. Retrieved from https://pdfs.semanticscholar.org/70a5/51583c5b8370 $82806368784 f 65011 \mathrm{~d} 90 \mathrm{a} 7 \mathrm{f7} . \mathrm{pdf}$

Fauzi, A, \& Sa'diyah, W. (2019). Students' metacognitive skills from the viewpoint of answering biological questions: Is it already good? Jurnal Pendidikan IPA Indonesia, 8(3), 317-327. doi: https://doi.org/10.15 294/jpii.v8i3.19457

Fauzi, Ahmad, \& Sa'diyah, W. (2019). The metacognition of pre-service biology teachers: Awareness, skills, understanding, and practices. Advances in Social Science, Education and Humanities Research, 349(6th International Conference on Community Development (ICCD 2019)), 27-32. Atlantis Press. doi: 
https://dx. doi.org/10.2991/iccd-19.2019.8

Gullan, R. L., Power, T. J., \& Leff, S. S. (2013). The role of empowerment in a school-based community service program with inner-city, minority youth. Journal of Adolescent Research, 28(6), 664-689. doi: https://doi.org/10.1177/0743558413477200

Hargrove, R. A., \& Nietfeld, J. L. (2015). The impact of metacognitive instruction on creative problem solving. Journal of Experimental Education, 83(3), 291-318. doi: https://doi.org/10.1080/00220973.2013.876604

Hartman, H. J. (2001). Metacognition in science teaching and learning. In H.J. Hartman (ed.) (Ed.), Metacognition in Learning and Instruction (pp. 173-201). doi: https://doi.org/10.1007/978-94-017-22438_9

Haryani, S., Masfufah, Wijayati, N., \& Kurniawan, C. (2018). Improvement of metacognitive skills and students' reasoning ability through problem-based learning. Journal of Physics: Conference Series, 983(1), 1-5. doi: https://doi.org/10.1088/1742-6596/983/1/012174

Jia, X., Li, W., \& Cao, L. (2019). The role of metacognitive components in creative thinking. Frontiers in Psychology, 10(2404), 1-11. doi: https://doi.org/10.3389/fpsyg.2019.02404

Jiang, Y., Ma, L., \& Gao, L. (2016). Assessing teachers' metacognition in teaching: The Teacher Metacognition Inventory. Teaching and Teacher Education, 59, 403-413. doi: https://doi.org/10.1016/j. tate.2016.07.014

Kemendikbud. (2014). Materi Pelatihan Implementasi Kurikulum 2013 di Tahun 2014. Retrieved from https://matematohir.files.wordpress.com/2013/07/materi-pelatihan-implementasi-kurikulum-2013-tahun2014.pdf

Lukitasari, M., Hasan, R., \& Murtafiah, W. (2019). Using critical analysis to develop metacognitive ability and critical thinking skills in biology. JPBI (Jurnal Pendidikan Biologi Indonesia), 5(1), 151-158. doi: https:/l doi.org/10.22219/jpbi.v5i1.7262

Magno, C. (2010). The role of metacognitive skills in developing critical thinking. Metacognition and Learning, 5(2), 137-156. doi: https://doi.org/10.1007/s11409-010-9054-4

Naimnule, L., \& Corebima, A. D. (2018). The correlation between metacognitive skills and critical thinking skills toward students' process skills in biology learning. Journal of Pedagogical Research, 2(2), 122134. Retrieved from https://www.ijopr.com/download/the-correlation-between-metacognitive-skills-andcritical-thinking-skills-toward-students-process-6384.pdf

Nurajizah, U., \& Windyariani, S. (2018). Improving students' metacognitive awareness through implementing learning journal. JPBI (Jurnal Pendidikan Biologi Indonesia), 4(2), 105-112. doi: https://doi.org/10.22219 /jpbi.v4i2.5788

Panchu, P., Bahuleyan, B., Seethalakshmi, K., \& Thomas, T. (2016). Metacognitive awareness- evaluation and implications in medical students. International Journal of Research in Medical Sciences, 4(8), 3570-3575. doi: https://doi.org/10.18203/2320-6012.jirms20162331

Pedone, F. (2014). How to improve metacognition in primary school. Proceedings of INTED2014 Conference, 1688-1698. Valencia. Retrieved from https://iris.unipa.it/retrieve/handle/10447/95020/121363/2014_INT ED1375.pdf

Persky, A. M., Medina, M. S., \& Castleberry, A. N. (2018). Developing critical thinking skills in pharmacy students. American Journal of Pharmaceutical Education, 83(2), 161-170. doi: https://doi.org/10.5688/aj pe7033

Rahmat, I., \& Chanunan, S. (2018). Open inquiry in facilitating metacognitive skills on high school biology learning: An inquiry on low and high academic ability. International Journal of Instruction, 11(4), 593606. doi: https://doi.org/10.12973/iji.2018.11437a

Schraw, G., \& Dennison, R. S. (1994). Assessing metacognitive awareness. Contemporary Educational Psychology, 19(4), 460-475. doi: https://doi.org/10.1006/ceps.1994.1033

Serdyukov, P. (2017). Innovation in education: What works, what doesn't, and what to do about it? Journal of Research in Innovative Teaching \& Learning, 10(1), 4-33. doi: https://doi.org/10.1108/rit-10-2016-0007

Setiawati, H., \& Corebima, A. D. (2018). Improving students' metacognitive skills through science learning by integrating PQ4R and TPS strategies at a senior high school in Parepare, Indonesia. Journal of Turkish Science Education, 15(2), 95-106. doi: https://doi.org/10.12973/tused.10233a

Sewagegn, A. A., \& Diale, B. M. (2019). Empowering learners using active learning in higher education institutions. In S. M. Brito (Ed.), Active Learning - Beyond the Future (pp. 118-414). doi: https://doi.org/1 0.5772/intechopen.80838

Siagian, M. V., Saragih, S., \& Sinaga, B. (2019). Development of learning materials oriented on problem- 
based learning model to improve students' mathematical problem solving ability and metacognition ability. International Electronic Journal of Mathematics Education, 14(2), 331-340. doi: https://doi.org/1 $0.29333 /$ iejme/5721

Siegesmund, A. (2016). Increasing student metacognition and learning through classroom-based learning communities and self-assessment. Journal of Microbiology \& Biology Education, 17(2), 204-214. doi: https://doi.org/10.1128/jmbe.v17i2.954

Siregar, I. Y., Susilo, H., \& Suwono, H. (2017). The effect of think-pair-share-write based on hybrid learning on metakognitive skills, creative thinking and cognitive learning at SMA Negeri 3 Malang. JPBI (Jurnal Pendidikan Biologi Indonesia), 3(2), 183-193. doi: https://doi.org/10.22219/jpbi.v3i2.4217

Sudarmin, S., Febu, R., Nuswowati, M., and Sumarni, W. (2016). Development of ethnoscience approach in the module theme substance additives to improve the cognitive learning outcome and student's entrepreneurship. IOP Conference Series: Journal of Physics, 824(2017) 012024, 1-14. doi: https://doi. org/10.1088/1742-6596/824/1/012024

Sudarmin, S. (2014). Model pembelajaran sains berbasis etnosains (MPSBE) untuk menanamkan nilai karakter konservasi dan literasi sains. Research Report. Retrieved from http://kinerja.unnes.ac.id/v2/ki nerja/download_bukti/548707/nancyyy

Sumampouw, H., Rengkuan, M., Siswati, B. H., \& Corebima, A. D. (2016). Metacognition skill development in genetic lecture at the State University of Malang Indonesia. International Journal of Educational Policy Research and Review, 3(3), 36-42. doi: http://dx.doi.org/10.15739/JJEPRR.16.006

Suratno, Komaria, N., Yushardi, Dafik, \& Wicaksono, I. (2019). The effect of using synectics model on creative thinking and metacognition skills of junior high school students. International Journal of Instruction, 12(3), 133-150. doi: https://doi.org/10.29333/iji.2019.1239a

Tamsyani, W. (2016). Pengaruh model pembelajaran dan kesadaran metakognitif terhadap hasil belajar peserta didik SMA dalam materi pokok asam basa. Journal of EST, 2(April), 10-25. doi: https://doi.org/ 10.26858/est.v2i1.1887

Tjalla, A., \& Putriyani, M. F. (2018). Mathematics metacognitive skills of Papua's students in solving mathematics problems. Asian Social Science, 14(7), 14-25. doi: https://doi.org/10.5539/ass.v14n7p14

Wilson, N. S., \& Bai, H. (2010). The relationships and impact of teachers' metacognitive knowledge and pedagogical understandings of metacognition. Metacognition and Learning, 5(3), 269-288. doi: https:/l doi.org/10.1007/s11409-010-9062-4

Yanqun, Z. (2019). The significance and instruction of metacognition in continuing education. International Forum of Teaching and Studies, 15(1), 29-37. Retrieved from https://www.questia.com/library/journal/ 1P4-2210885926/the-significance-and-instruction-of-metacognition

Yasir, M. (2015). Pengembangan perangkat pembelajaran berbasis metakognitif untuk meningkatkan atensi, keterampilan berpikir reflektif, dan kejujuran siswa (Unpublished Thesis). Universitas Negeri Surabaya.

Zohar, A., \& Barzilai, S. (2013). A review of research on metacognition in science education: current and future directions. Studies in Science Education, 49(2), 121-169. doi: https://doi.org/10.1080/03057267.2 013.847261

Zulfiani, Y. H., Rosyidatun, E. S., Hasiani, S., Rohmatullah, G., \& Zuqistya, N. (2018). Developing metacognitive skill instrument on fungus concept. Edusains, 10(2), 243-253. doi: https://doi.org/10.1540 8/es.v10i2.7919 